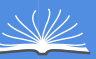

Global burnals Inc.

है

\title{
Determinants of Hypertension in a Rural Area of Kancheepuram District, Tamilnadu
}

By Dr. M. Vijayakarthikeyan \& Dr. Muthulakshmi Muthiah Institute of Medical and Technical Sciences (SIMATS)

Abstract- Background: Hypertension is one of the most important modifiable risk factors for cardiovascular diseases (CVDs). Hypertension is a risk factor that accounts for $12.3 \%$ of the deaths and disabilities combined in Tamilnadu during 2016.

Objectives

- To assess the prevalence of risk factors of hypertension among the study population.

- To determine the association between socio-demographic factors and hypertension.

- To determine the association between various risk factors and hypertension.

Keywords: blood pressure, risk factor, cardiovascular disease.

GJMR-B Classification: NLMC Code: WG 340

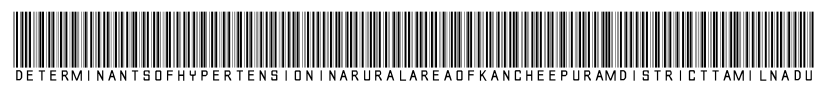

Strictly as per the compliance and regulations of:

(C) 2020. Dr. M. Vijayakarthikeyan \& Dr. Muthulakshmi Muthiah. This is a research/review paper, distributed under the terms of the Creative Commons Attribution-Noncommercial 3.0 Unported License http://creativecommons.org/licenses/by-nc/3.0/), permitting all non-commercial use, distribution, and reproduction in any medium, provided the original work is properly cited. 


\title{
Determinants of Hypertension in a Rural Area of Kancheepuram District, Tamilnadu
}

\author{
Dr. M. Vijayakarthikeyan ${ }^{\alpha}$ \& Dr. Muthulakshmi Muthiah ${ }^{\sigma}$
}

Abstract- Background: Hypertension is one of the most important modifiable risk factors for cardiovascular diseases (CVDs). Hypertension is a risk factor that accounts for $12.3 \%$ of the deaths and disabilities combined in Tamilnadu during 2016.

\section{Objectives}

- To assess the prevalence of risk factors of hypertension among the study population.

- To determine the association between sociodemographic factors and hypertension.

- To determine the association between various risk factors and hypertension.

Materials and methods: It is a community-based crosssectional study. The sample size calculated was 1250 and a systematic random sampling method was used. A pre-tested structured questionnaire was used to collect data from the study population. Information regarding socio-demographic characteristics, risk factors, regarding hypertension and physical measurements were obtained. The data analysis was done using SPSS software (version 22).

Results: Among the study population,23.6\% were hypertensive, and. in this study, $12.8 \%$ use tobacco in any form, $18.6 \%$ use alcohol, $66.2 \%$ of the participants are physically inactive, and $72.5 \%$ are consuming an unhealthy diet. In the Univariate analysis, the variables that are significantly associated with hypertension are age, marital status, education, occupation, socio-economic status, family type, positive family history, presence of associated comorbidities, knowledge about hypertension and BMI. In multivariate analysis are age, presence of associated comorbidities, knowledge about hypertension, family type, and BMI.

Conclusion: The prevalence of hypertension and its determinants is high in this study are tumultuous. Lifestyle modification plays a pivotal role, and hypertension is a lifestyle disease change in that harmful lifestyle habits must be adopted.

Keywords: blood pressure, risk factor, cardiovascular disease.

Author $\alpha$ : Assistant professor, Department of Community Medicine, Vinayaka Missions Kirupananda Variyar Medical College and Hospitals Salem, Tamilnadu, Vinayaka Missions Research Foundation (VMRF). e-mail: vijay.doc09@gmail.com

Author 6: Assistant professor, Department of Community Medicine, Saveetha Medical College and Hospitals Kancheepuram, Tamilnadu, Saveetha Institute of Medical and Technical Sciences (SIMATS) \& Vinayaka Missions Kirupananda Variyar Medical College and Hospitals Salem, Tamilnadu, Vinayaka Missions Research Foundation (VMRF).

\section{INTRODUCTION}

igh blood pressure (BP) is one of the most important modifiable risk factors for cardiovascular diseases (CVDs). ${ }^{1}$ Hypertension (HTN) is a chronic condition of concern because of its role in the causation of coronary heart disease (CHD), stroke, and other vascular complications. It is the most common CVD disorder which poses a significant public health challenge to a population undergoing socioeconomic evolution. It is one of the dominant risk factors for CVD mortality, accounting for $20-50 \%$ of all deaths. ${ }^{2,3}$ Hypertension (HTN) exerts a substantial public health burden on cardiovascular health status and healthcare systems in India. ${ }^{4,5}$

The analysis showed that about $26 \%$ of the population globally is suffering from hypertension, and the prevalence is higher among developed as compared to developing countries. ${ }^{6}$ It is predicted that the number of adults with hypertension would increase by about $60 \%$ to a total of 1.56 billion by $2025 .{ }^{7,8} \mathrm{HTN}$ is directly responsible for $57 \%$ of all stroke deaths and $24 \%$ of all coronary heart disease (CHD) deaths in India. ${ }^{9,10}$

Currently, the incidence of hypertension is 20 to $40 \%$ in urban areas and 12 to $17 \%$ in rural areas of India. One in three Indian adults has high blood pressure. According to the World Health Statistics 2012 report, India has low rates of hypertension compared to world figures. ${ }^{11}$ In India, $23.10 \%$ of men and $22.60 \%$ of women over 25 years suffer from hypertension. ${ }^{12,13} \mathrm{As}$ per the NFHS 4 report, prevalence of hypertension in males is $10.3 \%$ and in females is $6.7 \% .{ }^{14}$ Community surveys have documented that in a period of three to six decades, prevalence of hypertension has increased by about 30 times among the urban dwellers and by about ten times among the rural inhabitants. ${ }^{15,16}$

The technological and economic developments have reduced the physical activity of the people to a real large extent and increased the alcohol and tobacco use which are the vital causes for the rising burden of hypertension. ${ }^{17}$ The risk factors for non-communicable disease are grouped into three categories they are behavioral, metabolic and biochemical risk factors. Behavioral risk factors include tobacco use, alcohol use, unhealthy diet, and lack of physical activity. Metabolic risk factors include overweight, obesity, diabetes, and 
hypertension (HTN). Biochemical risk factors include hypercholesteremia and hypertriglyceridemia. ${ }^{18}$

To contain the increasing burden of NonCommunicable Diseases, Ministry of Health and Family Welfare, Government of India, has launched the National Programme on Prevention and Control of Diabetes, Cardiovascular Diseases and Stroke (NPDCS).$^{19} \mathrm{As}$ fewer studies has been undertaken in rural India, this study was planned to assess the determinants of hypertension among the rural population of Kancheepuram district of Tamil Nadu. This study will shed some light on the existing problem.

\section{il. Materials and Methods}

\section{a) Study design}

This study is a community-based crosssectional study conducted in a rural area of Kancheepuram district, Tamil Nadu.

\section{b) Study area}

The study was conducted in Serappanachery Padappai (S. Padappai), which is the rural field practice area of the Rural Health and Training Centre (RHTC) attached to our Institution (Sree Balaji medical college and hospital).

\section{c) Study population}

The study population included are those permanently residing in Serappana-chery Padappai and belonging to the adult age group of 20-60 years.

d) Study period

The study was conducted during December $1^{\text {st } 2018-M a y ~ 31^{\text {st }}}, 2019$.

\section{e) Sample size}

The sample size was calculated from a previous study conducted by Kishore $\mathrm{J}$ et al, in a rural area in 2016, the prevalence of hypertension recorded in this study was $14.1 \%{ }^{20}$ The sample size was calculated using the formula $\mathrm{N}=\mathrm{Z}^{2} \mathrm{pq} /[\mathrm{L}]^{2}$ where $\mathrm{Z}=1.96, \mathrm{p}=$ $14.1 \%, q=85.9$ (100-14.1), $L=2$. 115. Accounting $15 \%$ for non-response, the final sample size was calculated as 1245 (rounded off to 1250). [ $\mathrm{N}=1250$ ]

\section{f) Inclusion criteria}

The inclusion criteria for the study were the adult population of age group (20-60 years) residing in Serappanachery Padappaiand willing to participate in the study.

\section{g) Exclusion criteria}

The exclusion criteria for the study were females who were pregnant, psychiatric patients, who are severely ill, and those who didn't give consent to participate in the study was excluded.

\section{h) Sampling method}

A systematic random sampling technique was used to identify the study subjects. Sampling Interval
$(\mathrm{N} / \mathrm{n})$ is calculated as follows: [N= Total number of households in Padappai $=1851, \mathrm{n}=$ sample size $=$ 1250. $N / n=1851 / 1250=2]$. Thus alternate household is selected for identifying the adult population between 20 60 years of age.

\section{i) Study tool}

A structured questionnaire based on the $\mathrm{WHO}$ STEPS approach is used as a study stool for data collection, Details included in it are socio demographic profiles, details regarding risk factors for hypertension, and physical measurements (height, weight, waist circumference, and BP).

\section{j) Informed consent}

Informed Consent was obtained from each participant before the administration of the interview schedule.

\section{k) Ethical approval}

The study proposal was presented and was approved by the Institutional Ethics Committee.

\section{I) Operational definitions}

1. Tobacco user: ${ }^{21}$

Tobacco user was defined as individuals who had used any form of tobacco in the last 30 days.

2. Alcohol user: ${ }^{21}$

Alcohol users were those who had consumed at least one standard drink of alcohol $(30 \mathrm{ml}$ of spirits, $285 \mathrm{ml}$ of beer, or $120 \mathrm{ml}$ of wine) in the last 12 months.

3. Unhealthy diet: ${ }^{18}$

A unhealthy diet is Low consumption of fruits and vegetables at less than five servings per day (one cup of raw leafy vegetables or a half cup of other vegetables (cooked) was considered one serving. One medium-sized piece of fruit or half cup of chopped fruit was measured as one serving).

4. Physical activity: ${ }^{18}$

Physical activity low physical activity was defined as $<150$ minutes of moderate physical activity per week.

5. Overweight:22

Overweight was defined as BMI $23-24.9 \mathrm{~kg} / \mathrm{m} 2$.

6. Pre obese:22

Pre obese was defined as BMl equal to or more than $25 \mathrm{~kg} / \mathrm{m} 2$.

7. Obese:22

Obese was defined as BMl equal to as or more than $30 \mathrm{~kg} / \mathrm{m} 2$.

8. Central obesity: ${ }^{22}$

Central obesity is assessed based on the waist-hip ratio. As per WHO guideline, males with a waist-hip ratio above 0.9 and females with a waist-hip ratio above 0.85 have central obesity. 


\section{Results}

a) Socio-demographic characteristics of the study population

Socio-demographic characteristics of the study population are shown in Table 1. Among the study participants, $44.2 \%$ belonged to $50-60$ years of age, $24.2 \%$ belonged to $20-30$ years of age, and $20.8 \%$ belonged to $30-40$ years of age. About $57.4 \%$ of the study participants were females, and $42.6 \%$ were males. Nearly $82.4 \%$ are married, and $5.44 \%$ were unmarried. Almost $18.7 \%$ of the study samples had no formal education, 30.2\% had middle school education, and $21.3 \%$ had a high school education. Among the participants, around $43.7 \%$ were unemployed, $32.2 \%$ are engaged in unskilled occupation, and $17.8 \%$ are involved in semiskilled occupation.49.6\% belonged to lower- middle socio-economic category, and $21.8 \%$ belonged to the upper lower socio-economic group. In this study, $56.8 \%$ of them belong to the nuclear family, $30 \%$ belonged to the joint family, and the rest were belonging to three-generation family.

Table 1: Socio Demographic Characteristics of the Study Population

\begin{tabular}{|c|c|c|c|}
\hline SI. No. & $\begin{array}{c}\text { Socio-Demographic } \\
\text { Variable }\end{array}$ & Frequency $(N=1250)$ & Percentage (\%) \\
\hline 1. & \multicolumn{3}{|c|}{ Age } \\
\hline & 20-30 Years & 136 & 10.9 \\
\hline & 30-40 Years & 302 & 24.2 \\
\hline & 40-50 Years & 260 & 20.8 \\
\hline & 50-60 Years & 552 & 44.2 \\
\hline \multirow[t]{3}{*}{2.} & \multicolumn{3}{|c|}{ Sex } \\
\hline & Male & 532 & 42.6 \\
\hline & Female & 718 & 57.4 \\
\hline \multirow[t]{5}{*}{3.} & \multicolumn{3}{|c|}{ Marital Status } \\
\hline & Unmarried & 68 & 5.4 \\
\hline & Married & 1030 & 82.4 \\
\hline & Widower & 142 & 11.4 \\
\hline & Divorcee & 10 & .8 \\
\hline \multirow[t]{8}{*}{4.} & \multicolumn{3}{|c|}{ Education } \\
\hline & Illetereate & 234 & 18.7 \\
\hline & Primary School & 282 & 22.6 \\
\hline & Middle School & 378 & 30.2 \\
\hline & High School & 266 & 21.3 \\
\hline & Post High School Diploma & 12 & 1.0 \\
\hline & $\mathrm{Ug} / \mathrm{Pg}$ & 72 & 5.8 \\
\hline & Professional & 6 & .5 \\
\hline \multirow[t]{8}{*}{5.} & \multicolumn{3}{|c|}{ Occupation } \\
\hline & Unemployed & 546 & 43.7 \\
\hline & Unskilled & 402 & 32.2 \\
\hline & Semiskilled & 222 & 17.8 \\
\hline & Skilled & 46 & 3.7 \\
\hline & Farmers/Clerks/Shop Owners & 10 & .8 \\
\hline & Semiprofessional & 14 & 1.1 \\
\hline & Professional & 10 & .8 \\
\hline
\end{tabular}




\begin{tabular}{|c|l|c|c|}
\hline \multirow{2}{*}{6.} & \multicolumn{3}{|c|}{ Socio Economic Status } \\
\hline \multirow{3}{*}{} & Upper & 90 & 7.2 \\
\cline { 2 - 4 } & Upper Middle & 234 & 18.7 \\
\cline { 2 - 4 } & Lower Middle & 620 & 49.6 \\
\cline { 2 - 4 } & Upper Lower & 272 & 21.8 \\
\cline { 2 - 4 } & Lower & 34 & 2.7 \\
\hline 7. & \multicolumn{1}{|c|}{ TYPE OF FAMILY } & \\
\hline \multirow{3}{*}{7.} & 710 & 36.8 \\
\cline { 2 - 4 } & Nuclear Family & 438 & 8.2 \\
\cline { 2 - 4 } & Joint Family & 102 & \\
\cline { 2 - 4 } & Three Generation Family & & \\
\hline
\end{tabular}

b) Prevalence of hypertension

The prevalence of hypertension is depicted in hypertension in this study is $23.8 \%$ (298). This includes both known hypertensives and newly diagnosed.

FIGURE 1.as we can see, the prevalence of

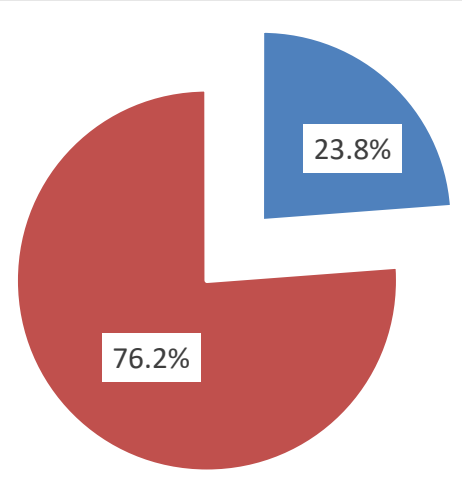

- Hypertensive - Non hyertensive

Fig. 1: Food habits of the study population

As we can see from TABLE 2, nearly $89.9 \%$ of had nonvegetarian once a week, and 35.1 had the study participants were nonvegetarian, and $10.1 \%$ nonvegetarian twice a week.

were vegetarian. Among the non-vegetarians, 54.1\%

Table 2: Food Habits of the Study Population

\begin{tabular}{|c|c|c|c|}
\hline SI. No. & Food Habits & FREQUENCY & PERCENTAGE (\%) \\
\hline 1. & \multicolumn{3}{|c|}{ Food Type (N-1250) } \\
\hline & Vegetarian & 126 & 10.1 \\
\hline & Non Vegetarian & 1124 & 89.9 \\
\hline \multirow[t]{6}{*}{2.} & \multicolumn{3}{|c|}{ Frequency of Non-Veg Intake (N-1124) } \\
\hline & Once A Week & 608 & 54.1 \\
\hline & Twice A Week & 394 & 35.1 \\
\hline & Thrice A Week & 104 & 9.2 \\
\hline & Four Times A Week & 12 & 1.1 \\
\hline & $>$ Four Times A Week & 6 & 0.5 \\
\hline
\end{tabular}


c) Lifestyle characteristics of the study population

Lifestyle characteristics of the study population are shown in TABLE $3.60 .2 \%$ of them are involved in sedentary work, and $35.5 \%$ were engaged in the moderate type of work. Only $21.4 \%$ have the habit of doing regular physical exercise. Among them, 39.6\% do it for $1-2$ hours per week and $27.7 \%$ do it for $2-5$ hours a week.

Table 3: Lifestyle Characteristics of the Study Population

\begin{tabular}{|c|c|c|c|}
\hline SI. No. & Lifestyle & FREQUENCY & PERCENTAGE (\%) \\
\hline 1. & \multicolumn{2}{|c|}{ Job Type (N-1250) } \\
\hline \multirow{3}{*}{} & Sedentary Work & 752 & 60.2 \\
\cline { 2 - 4 } & Moderate Work & 444 & 35.5 \\
\cline { 2 - 4 } & Heavy Work & 54 & 4.3 \\
\hline \multirow{2}{*}{2.} & \multicolumn{3}{|c|}{ Exercise (N-1250) } \\
\hline \multirow{4}{*}{3.} & Yes & 268 & 21.4 \\
\cline { 2 - 4 } & No & 982 & 78.6 \\
\hline \multirow{2}{*}{3.} & $<1$ Hour/Week & 20 & 7.4 \\
\cline { 2 - 4 } & 1-2 Hours/ Week & 106 & 39.6 \\
\cline { 2 - 4 } & 2--5 Hours/ Week & 74 & 27.7 \\
\cline { 2 - 4 } & $>5$ Hours/ Week & 68 & 25.3 \\
\hline
\end{tabular}

Table 4: Prevalence of Behavioural Risk Factors Among the Study Population

\begin{tabular}{|c|c|c|c|}
\hline SI. No. & Risk Factor & $\begin{array}{c}\text { Frequency } \\
(\mathrm{N}-1250)\end{array}$ & Percentage (\%) \\
\hline \multirow[t]{3}{*}{1.} & \multicolumn{3}{|c|}{ Tobacco Use } \\
\hline & Yes & 160 & 12.8 \\
\hline & No & 1090 & 87.2 \\
\hline \multirow[t]{3}{*}{2.} & \multicolumn{3}{|c|}{ Alcohol Use } \\
\hline & Yes & 232 & 18.6 \\
\hline & No & 1018 & 81.4 \\
\hline 3. & \multicolumn{3}{|c|}{ Physical Inactivity } \\
\hline & Yes & 828 & 66.2 \\
\hline & No & 422 & 33.8 \\
\hline 4. & \multicolumn{3}{|c|}{ Unhealthy Diet } \\
\hline & Yes & 906 & 72.5 \\
\hline & No & 344 & 27.5 \\
\hline
\end{tabular}

d) Prevalence of risk factors among the study population

Prevalence of risk factors for hypertension is depicted in TABLE 4 and 5 .in this study $12.8 \%$ use tobacco in any form, $18.6 \%$ use alcohol, $66.2 \%$ of the participants are physically inactive, and $72.5 \%$ are consuming an unhealthy diet. Among the study participants, $21.4 \%$ had a positive family history of hypertension, $3 \%$ of them are under oral contraceptive pills, and $24.8 \%$ are suffering from various comorbidties (TABLE 5). 
Table 5: Associated Risk Factors among Study Population

\begin{tabular}{|c|c|c|c|}
\hline \hline \multirow{2}{*}{ SI. No. } & Risk Factors & $\begin{array}{c}\text { Frequency } \\
(\mathrm{N}-1250)\end{array}$ & Percentage (\%) \\
\hline 1. & Family History of Hypertension (N-1250) \\
\hline \multirow{2}{*}{} & YES & 268 & 21.4 \\
\hline 2. & NO & 982 & 78.6 \\
\hline \multirow{3}{*}{3.} & OCP Pill Intake Among Females (N-718) \\
\hline & YES & 38 & 3.0 \\
\hline & NO & 680 & 97.0 \\
\hline & YES & 310 & 24.8 \\
\hline
\end{tabular}

e) Prevalence of obesity among the study population As per the Asian Adults BMI criteria (FIGURE 2), 26.2\% were overweight, $22 . \%$ were pre-obese and
$12.6 \%$ belonged to the obese category. Central obesity was assessed based on the waist-hip ratio. About $83.4 \%$ of the study participants have central obesity.

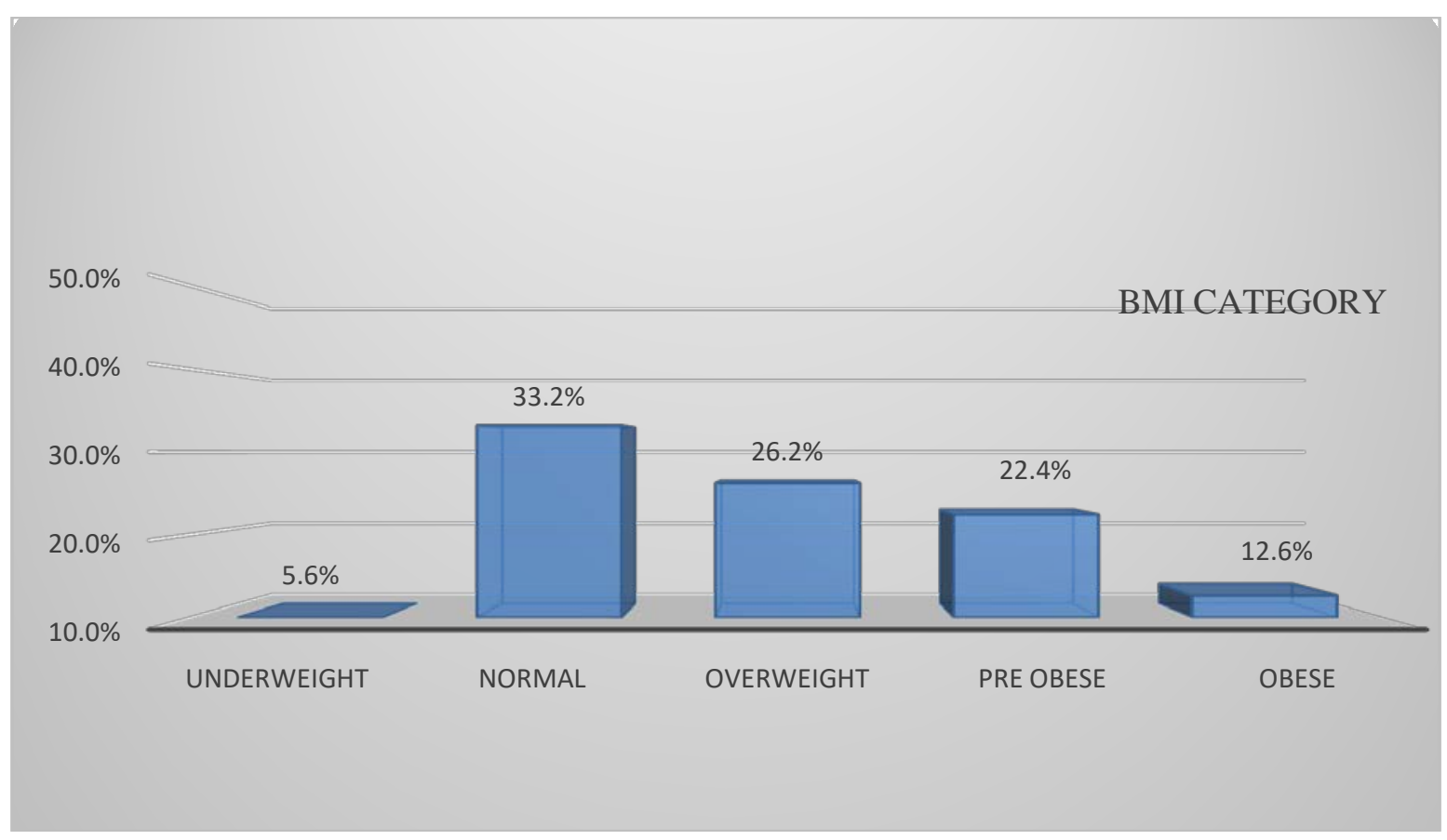

Figure 2: Bmi Classification of the Study Population

Among the males, $86.5 \%$ have central obesity, and $80.3 \%$ of females have central obesity in this study (FIGURE 3). 


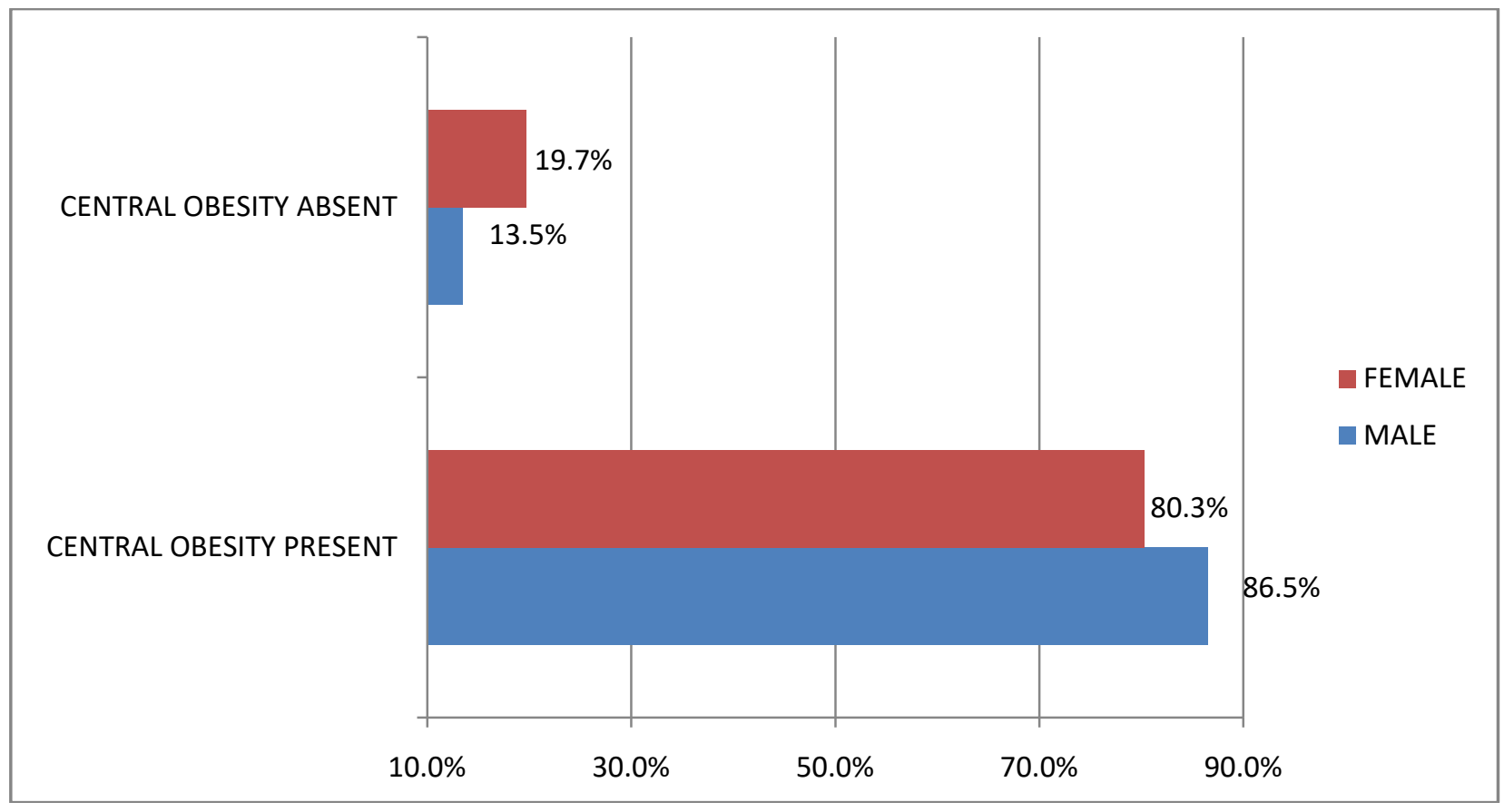

Figure 3: Prevalence of Central Obesity among the Study Population

f) Knowledge regarding hypertension among the study population

Among the study participants, when asked whether they know the normal blood pressure value, $24.8 \%$ said they know the normal blood pressure value., and among them, only $60 \%$ said the correct blood pressure value and $40 \%$ said incorrect value. In this study, $47.5 \%$ of the participants have adequate knowledge about hypertension, as shown in FIGURE 4.

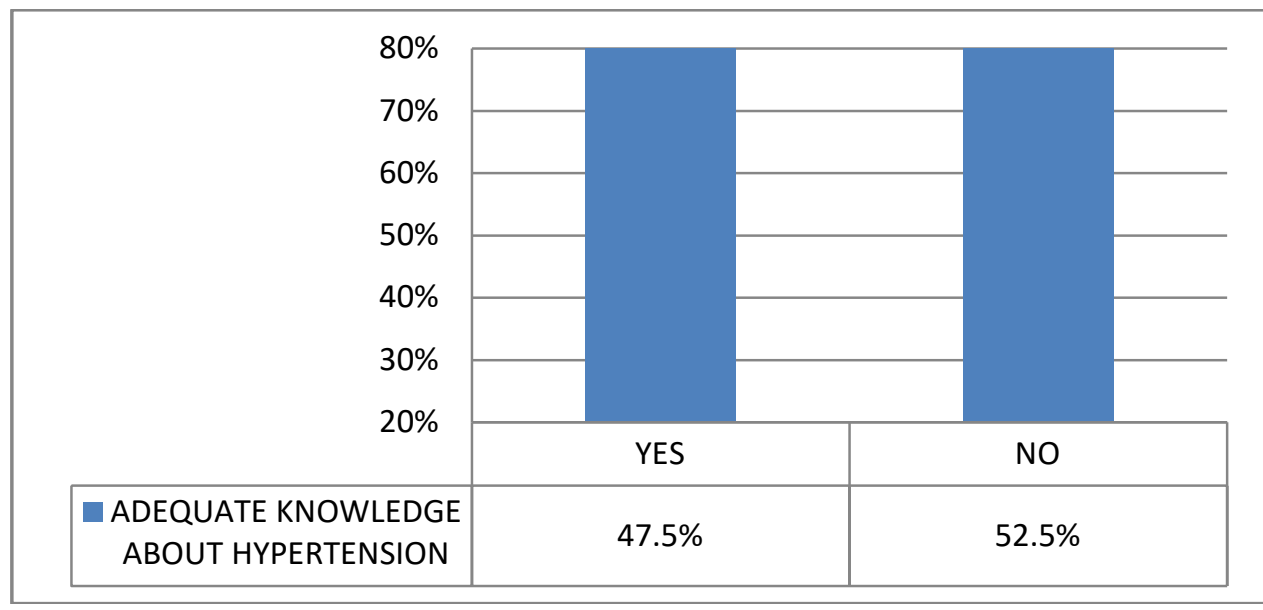

Figure 4: Adequate Knowledge Regarding Hypertension Among The Study Population

g) Univariate analysis findings among the study population

In the Univariate analysis the variables that are significantly associated with hypertension are age ( $p$ value- $<0.0001)$, marital status ( $p$-value- $<0.0001$ ), education ( $p$-value-0.015), occupation ( $p$-value-0.003), socio-economic status ( $p$-value- $<0.015)$, family type ( $p$ value- $<0.0001$ ), positive family history ( $p$-value-0.009), presence of associated comorbidity ( $p$-value- $<0.0001$ ), knowledge about hypertension $(p-$ value- $<0.0001)$ and
BMI (p-value-<0.0001). There was no association found between other variables and hypertension. 
Table 7: Univariate Analysis Findings

\begin{tabular}{|c|c|c|c|c|c|}
\hline \multirow[b]{2}{*}{ Variable } & \multirow[b]{2}{*}{$\begin{array}{l}\text { Total Frequency } \\
(\mathrm{N}-1250)\end{array}$} & \multicolumn{4}{|c|}{ Hypertension } \\
\hline & & $\begin{array}{l}\text { FREQUENCY } \\
(\mathrm{N}-298)\end{array}$ & $\begin{array}{l}\text { CHI- } \\
\text { SQUARE } \\
\text { VALUE }\end{array}$ & P VALUE & $\begin{array}{l}\text { ODDS RATIO } \\
(95 \% \mathrm{Cl})\end{array}$ \\
\hline $\begin{array}{l}\text { Age } \\
>40 \text { Years } \\
<40 \text { Years }\end{array}$ & $\begin{array}{l}438 \\
812\end{array}$ & $\begin{array}{c}264 \\
34\end{array}$ & 124.387 & $<0.0001^{\star * *}$ & $\begin{array}{c}5.724 \\
3.916-8.366\end{array}$ \\
\hline $\begin{array}{l}\text { Sex } \\
\text { Female } \\
\text { Male }\end{array}$ & $\begin{array}{l}532 \\
718\end{array}$ & $\begin{array}{l}168 \\
130\end{array}$ & 0.181 & 0.670 & $\begin{array}{c}0.949 \\
0.730-1.234\end{array}$ \\
\hline $\begin{array}{l}\text { Marital Status } \\
\text { Married } \\
\text { Unmarried/Divorce } \\
\text { Widower }\end{array}$ & $\begin{array}{c}1030 \\
120\end{array}$ & $\begin{array}{c}226 \\
72\end{array}$ & 23.943 & $<0.0001^{\star \star *}$ & $\begin{array}{c}17.051 \\
12.407-23.434\end{array}$ \\
\hline $\begin{array}{l}\text { Education } \\
\geq \text { High School Education } \\
<\text { High School Education }\end{array}$ & $\begin{array}{l}356 \\
894\end{array}$ & $\begin{array}{c}91 \\
207\end{array}$ & 15.828 & $0.015^{\star *}$ & $\begin{array}{c}1.139 \\
0.857-1.514\end{array}$ \\
\hline $\begin{array}{l}\text { Occupation } \\
\geq \text { Skilled } \\
<\text { Skilled }\end{array}$ & $\begin{array}{c}80 \\
1120\end{array}$ & $\begin{array}{c}22 \\
276\end{array}$ & 19.501 & $0.003^{* * *}$ & $\begin{array}{c}1.225 \\
0.736-2.039\end{array}$ \\
\hline $\begin{array}{l}\text { Socioeconomic Status } \\
\text { Upper / Middle Class } \\
\text { Lower Class }\end{array}$ & $\begin{array}{l}944 \\
306\end{array}$ & $\begin{array}{c}227 \\
71\end{array}$ & 12.295 & $0.015^{\star *}$ & $\begin{array}{c}1.047 \\
0.772-1.420\end{array}$ \\
\hline $\begin{array}{l}\text { Family Type } \\
\text { Joined/Three Generation Family } \\
\text { Nuclear Family }\end{array}$ & $\begin{array}{l}540 \\
710\end{array}$ & $\begin{array}{l}158 \\
140\end{array}$ & 22.244 & $<0.0001^{* * *}$ & $\begin{array}{c}1.684 \\
1.296-2.188\end{array}$ \\
\hline $\begin{array}{l}\text { Tobacco Use } \\
\text { Yes } \\
\text { No }\end{array}$ & $\begin{array}{c}160 \\
1090\end{array}$ & $\begin{array}{c}33 \\
265\end{array}$ & 1.045 & 0.307 & $\begin{array}{c}0.808 \\
0.538-1.125\end{array}$ \\
\hline $\begin{array}{l}\text { Alcohol Use } \\
\text { Yes } \\
\text { No }\end{array}$ & $\begin{array}{c}232 \\
1018\end{array}$ & $\begin{array}{c}59 \\
239\end{array}$ & 0.397 & 0.529 & $\begin{array}{c}1.111 \\
0.799-1.544\end{array}$ \\
\hline $\begin{array}{l}\text { Unhealthy Diet } \\
\text { Yes } \\
\text { No }\end{array}$ & $\begin{array}{l}906 \\
344\end{array}$ & $\begin{array}{c}221 \\
77\end{array}$ & 0.554 & 0.457 & $\begin{array}{c}1.187 \\
0.832-1.503\end{array}$ \\
\hline $\begin{array}{l}\text { Physical Inactivity } \\
\text { Yes } \\
\text { No }\end{array}$ & $\begin{array}{l}828 \\
422\end{array}$ & $\begin{array}{l}194 \\
104\end{array}$ & 3.427 & 0.180 & $\begin{array}{c}0.940 \\
0.715-1.235\end{array}$ \\
\hline $\begin{array}{l}\text { Positive Family History } \\
\text { Yes } \\
\text { No }\end{array}$ & $\begin{array}{l}268 \\
982\end{array}$ & $\begin{array}{c}80 \\
218\end{array}$ & 6.788 & $0.009^{* * *}$ & $\begin{array}{c}1.491 \\
1.102-2.016\end{array}$ \\
\hline $\begin{array}{lll}\text { Presence } & \text { of } & \text { Associated } \\
\text { Comorbidity } & & \\
\text { Yes } & & \\
\text { No } & & \end{array}$ & $\begin{array}{l}310 \\
940\end{array}$ & $\begin{array}{l}129 \\
169\end{array}$ & 71.718 & $<0.0001^{\star \star \star}$ & $\begin{array}{c}3.251 \\
2.456-4.304\end{array}$ \\
\hline $\begin{array}{l}\text { Knowledge About Hypertension } \\
\text { Yes } \\
\text { No }\end{array}$ & $\begin{array}{l}570 \\
680\end{array}$ & $\begin{array}{c}204 \\
94\end{array}$ & 58.774 & $<0.0001^{\star \star \star}$ & $\begin{array}{c}3.071 \\
2.329-4.050\end{array}$ \\
\hline $\begin{array}{l}\text { Bmi } \\
\text { Overweight/Preobese/Obese } \\
\text { Underweight/Normal }\end{array}$ & $\begin{array}{l}765 \\
485\end{array}$ & $\begin{array}{c}234 \\
64\end{array}$ & 20.277 & $<0.0001^{* * *}$ & $\begin{array}{c}2.886 \\
2.128-3.914\end{array}$ \\
\hline
\end{tabular}

** $P$ value $<0.05$ is significant and ${ }^{* *} P$ value $<0.01$ is highly significant

h) Multivariate analysis findings among the study population

The variables which were significantly associated in Univariate analysis were only included in the multivariate analysis which is shown in TABLE 8. The multivariate analysis was done using the Enter method. The Model was found to be statistically significant (Cox and Snell R2 - 0.240, Nagelkerke R2 -0.3660, P-value
$<0.001)$. The variables that are significant in multivariate analysis are age, presence of associated comorbidity, family type, and BMI,Other variables were found to be insignificant in multivariate analysis. 
Table 8: Multivariate Analysis Findings

\begin{tabular}{|c|c|c|c|c|}
\hline \multirow{2}{*}{ Variable } & \multicolumn{4}{|c|}{ Hypertension } \\
\hline & $P$ Value & Adjusted Or & $95 \% \mathrm{Ci}$ & Nagelkerke R Square Value \\
\hline Age & $<0.0001$ & 0.417 & $0.341-0.510$ & \multirow{5}{*}{0.360} \\
\hline Marital Status & 0.235 & 0.807 & $0.567-1.149$ & \\
\hline Education & 0.266 & 0.925 & $0.806-1.061$ & \\
\hline Occupation & 0.397 & 0.935 & $0.393-1.093$ & \\
\hline Socio Economic Status & 0.556 & 1.058 & $0.877-1.276$ & \\
\hline Positive Family History & 0.117 & 1.343 & $0.929-01.944$ & \multirow[t]{2}{*}{ Cox And Snell R Square Value } \\
\hline $\begin{array}{l}\text { Presence of Associated } \\
\text { Comorbidity }\end{array}$ & $<0.0001$ & 2.516 & $1.806-3.505$ & \\
\hline $\begin{array}{ll}\text { Knowledge } & \text { About } \\
\text { Hypertension } & \end{array}$ & $<0.0001$ & 2.712 & $1.958-3.756$ & \multirow[t]{3}{*}{0.240} \\
\hline Bmi & $<0.0001$ & 0.530 & $0.459-0.611$ & \\
\hline Family Type & 0.0001 & 0.656 & $0.517-0.832$ & \\
\hline
\end{tabular}

** $P$ value $<0.05$ is significant and $* * * P$ value $<0.01$ is highly significant

\section{Discussion}

\section{a) Risk factors for hypertension}

\section{i. Tobacco use}

In this study among the study participants, $12.8 \%$ use tobacco and of which $3.5 \%$ use smokeless tobacco. In a study, by Chataut J, $40.2 \%$ of the study population has smoking habit. ${ }^{23} 25.5 \%$ of the ever used tobacco in a study by Maroof KA In Uttar Pradesh. ${ }^{24}$ In Peter Lloyd-Sherlock study $64.6 \%$ had never smoked and $24.1 \%$ are smoking daily. ${ }^{25} 15.9 \%$ are smoking daily, and $73.2 \%$ are using smokeless tobacco in a study by Aroor Bhagyalaxmi which was conducted in a rural area of Gujarat, India. ${ }^{26}$ Sathish Kumar conducted a study in Salem in which $24.7 \%$ had never used tobacco, and $25 \%$ are past users. ${ }^{21}$

\section{ii. Alcohol use}

In this stud, $18.6 \%$ are current alcohol users, and $1.1 \%$ were past users of alcohol. Sathish Kumar's study showed that $58.3 \%$ are using alcohol daily or a few days a week, and $28.6 \%$ had used alcohol in the past. ${ }^{21} 40.9 \%$ are consuming alcohol in a study by Chataut $\mathrm{J} .{ }^{23}$ In a study by K. A. Maroof,35.5\% had ever used alcohol,, and the remaining $64.5 \%$ had never used alcohol. ${ }^{24} 76.8 \%$ had never consumed alcohol in their lifetime in a study conducted by Peter Lloyd-Sherlock. ${ }^{25}$

\section{iii. Physical activity}

In this study, 66.2\% were physically inactive, and only $33.8 \%$ were physically active as per the operational definition, and this showed that the majority of the study participants are following unhealthy lifestyle habits. In Chataut J study, $51.8 \%$ are involved in moderate physical activity, and $8 \%$ are engaged in sedentary activities. ${ }^{23} 28.5 \%$ are physically inactive in a study done by Peter Lloyd-Sherlock. ${ }^{25}$ Aroor Bhagyalaxmi study showed that $14.1 \%$ of the study samples were physically inactive. ${ }^{26} 34.9 \%$ were doing sedentary physical activity and $33.8 \%$ are involved in vigorous physical activities in a study done by Sathish Kumar. ${ }^{21}$

\section{iv. Unhealthy diet}

$72.5 \%$ of the respondents in this study were following an unhealthy diet. In a study conducted by Aroor Bhagyalaxmi most of the study participants i.e. $96.4 \%$ were following unhealthy diet. ${ }^{26} 94.5 \%$ were taking low fruit, and vegetables in a study by Garg A. ${ }^{27}$ Bhattacherjee $S$ conducted a study in West Bengal in which $60.4 \%$ were consuming an unhealthy diet. ${ }^{28}$

\section{v. Overweight and obesity}

In this study, as per the Asian Adults BMI criteria, $26.2 \%$ were overweight, $22 \%$ were pre-obese, and $12.6 \%$ belonged to obese category. In $\vee$ Mohan study $22.5 \%$ were overweight and $28.5 \%$ of the respondents are obese. ${ }^{29} 12 \%$ of the respondents were overweight in a study by Aroor Bhagyalaxmi. ${ }^{26}$ In a study done by Prabhakaran D 35\% of them were overweight, and $3.3 \%$ of the study participants belonged to theobese category. ${ }^{30} 20.5 \%$ were overweight, and $4.2 \%$ were the obese in Midha T. ${ }^{31}$

\section{vi. Central obesity}

In this study, central obesity was assessed based on the waist-hip ratio. About $83.4 \%$ of the study participants have central obesity. In a study by Isezuo SA. $13 \%$ of the study participants had central obesity. ${ }^{32}$ Aroor Bhagyalaxmi showed that central obesity was present in $38 \%$ of the samples. ${ }^{26} 15.7 \%$ of the study participants have central obesity in AK Agarwal study. ${ }^{33}$ In a study by $\mathrm{K}$. A. Maroof $30.5 \%$ were centrally obese. ${ }^{24} 49.1 \%$ have central obesity in a study by $\mathrm{V}$ Mohan. ${ }^{29}$

\section{vii. Food habits}

In this study, nearly $89.9 \%$ of the study participants were nonvegetarian and $10.1 \%$ were vegetarian. Among the non vegetarians, $54.1 \%$ had non vegetarian food once a week, and 35.1 had non vegetarian food twice a week. In Chataut J study, 91.3\% of them are were nonvegetarian and $8.7 \%$ were vegetarian. ${ }^{23}$ Ina study by K. A. Maroof, $86.6 \%$ were vegetarian, and $13.4 \%$ were nonvegetarian. ${ }^{24} 28.6 \%$ were 
vegetarian and $71.4 \%$ were nonvegetarian in a study by Sathish Kumar. ${ }^{21}$

\section{viii. Family history of hypertension}

In this study, among the study participants, 21.4 $\%$ had a positive family history of hypertension. Rajeev Bhardwaj conducted a study in which only $4 \%$ of the study participants have a positive family history of hypertension. ${ }^{34}$ In a study by Shyamal Kumar Das, 2.4\% of the study participants had a positive family history of hypertension. ${ }^{35} 53.8 \%$ of the families have hypertension in a study by Haresh Chandwani. ${ }^{37}$

b) Association between sociodemographic variables, risk factors and hypertension

In this study in the Univariate analysis, the variables that are significantly associated with hypertension are age, marital status, education, occupation, socio-economic status, family type, positive family history, presence of associated comorbidity, knowledge about hypertension, and BMI. The variables that are significant in multivariate analysis are age, presence of associated comorbidity, knowledge about hypertension, family type, and BMI. In a study by Sathish Kumar, increasing age, male gender, increasing BMI levels, tobacco, alcohol, WHR were found to be significant independent predictors of hypertension and on multivariate analysis of these significant variables age, male gender, increasing BMI levels, were found to be significant after adjusting for other variables. ${ }^{21}$ In hypertension study group multicentric study multiple logistic regression analyses identified a higher body mass index, higher education status, and prevalent diabetes mellitus as important correlates of the prevalence of hypertension. ${ }^{37}$ Jonas JB conducted a study, in which hypertension was associated with higher age, higher body mass index, body height, Higher blood hemoglobin levels, and elevated blood urea concentration. $^{38}$

\section{Conclusion}

The prevalence of hypertension and its determinants is high in this study are tumultuous. Lifestyle modification plays a pivotal role, and hypertension is a lifestyle disease change in that harmful lifestyle habits must be adopted. The target population for this strategy will be adolescents, and early adults, as the prevention of risk factors will curb the rates of hypertension and its risk factors.

This study will initiate an internalization process of the government sector to make it more attractive, viable, and reliable, thereby giving scope proper screening, early diagnosis and treatment, and to provide accessible quality tertiary care.

\section{References Références Referencias}

1. World Health Organization 2012 hypertension report available at http://www.who.int/mediacentre/ factsheets/fs317/en/index.html, accessed on 15 April 2018.

2. Park K. Epidemiology of chronic non-communicable diseases and conditions. Park's Textbook of Preventive and Social Medicine. 18th ed. Jabalpur, India: Banarasidas Bhanot Publishers; 2005; p. 293.

3. Bhadoria AS, Kasar PK, Toppo NA, Bhadoria P, Pradhan S, Kabirpanthi V. Prevalence of hypertension and associated cardiovascular risk factors in Central India. Journal of family \& community medicine. 2014 Jan; 21(1):29.

4. Leeder S, Raymond S, Greenberg H, Liu H. A race against time. The challenge of cardiovascular disease in developing economies. New York: Columbia University; 2004.

5. Srinath Reddy K, Shah B, Varghese C, Ramadoss A. Responding to the threat of chronic diseases in India. Lancet 2005; 366:1744-1749.

6. World Health Organization. Global health risks: Mortality and burden of disease attributable to selected major risks. Geneva: World Health Organization; 2009.

7. Kearney PM, Whelton M, Reynolds K, Muntner P, Whelton PK, He J. Global burden of hypertension: Analysis of worldwide data. Lancet 2005; 365:21723.

8. Meshram II, Arlappa N, Balkrishna N, Rao KM, Laxmaiah A, Brahmam GN. Prevalence of hypertension, its correlates and awareness among adult tribal population of Kerala state, India. Journal of postgraduate medicine. 2012 Oct 1;58(4):255.

9. Gupta R. Trends in hypertension epidemiology in India. J Hum Hypertens 2004; 18:73-78.

10. Anchala R, Kannuri NK, Pant $H$, Khan H, Franco $\mathrm{OH}, \mathrm{Di}$ Angelantonio E, Prabhakaran D. Hypertension in India: a systematic review and meta-analysis of prevalence, awareness, and control of hypertension. Journal of hypertension. 2014 Jun; 32(6):1170.

11. World Health Organization. World health statistics report 2012.

12. WHO. World Health Statistics. Geneva: World Health Organization; 2013. Available at http://www.who.in /gho/publications/world_health_statistics/EN_WHS2 012 pdf.,

a. accessed on 6 May 2018.

13. Kumar KS, Ganapathi KC, Duraimurugan M, Selavaraj R, Kokila K, Megala M. Prevalence, awareness, treatment and control of hypertension in a rural community of Salem, Tamil Nadu. International Journal of Community Medicine and Public Health. 2017 May 22;4(6):1976-81.

14. NFHS 4 India 2015-16 report available at http://rchiips.org/NFHS/NFHS-4Reports/TamilNadu. pdf, accessed on 6 May 2018. 
15. Gupta R. Meta-analysis of prevalence of hypertension in India. Indian Heart J. 1997; 49: 4348.

16. Kokiwar PR, Gupta SS, Durge PM. Prevalence of hypertension in a rural community of central India. J Assoc Physicians India. 2012 Jun;60(6):26-9.

17. World Health Organization: Community Prevention and Control of Cardiovascular Diseases: WHO Tech Rep Series 1986; 732.

18. Vijayakarthikeyan M, Krishnakumar J, Umadevi R. Cross-sectional study on the prevalence of risk factors for non-communicable disease in a rural area of Kancheepuram, Tamil Nadu. International Journal Of Community Medicine And Public Health. 2017 Nov 23;4(12):4600-7.

19. Park K. Epidemiology of Chronic Non communicable diseases and condition; p-362.Park's Textbook of Preventive and Social Medicine.23rd ed. Jabalpur: Bhanot; 2015.

20. Kishore J, Gupta N, Kohli C, Kumar N. Prevalence of hypertension and determination of its risk factors in rural Delhi. International journal of hypertension. 2016;2016.

21. Sathish T, Kannan S, Sarma PS, Razum O, Thankappan KR. Incidence of hypertension and its risk factors in rural Kerala, India: a communitybased cohort study. Public health. 2012;126(1):2532.

22. Snehalatha $C$, Viswanathan $V$, Ramachandran A. Cutoff values for normal anthropometric variables in Asian Indian adults. Diabetes care. 2003 May 1;26(5):1380-4.

23. Chataut J, Adhikari RK, Sinha NP. The prevalence of and risk factors for hypertension in adults living in central development region of Nepal. Kathmandu Univ Med J. 2011 Jan;33(1):13-8.

24. Maroof KA, Parashar P, Bansal R, Ahmad S. A study on hypertension among the bank employees of Meerut district of Uttar Pradesh. Indian journal of public health. 2007 Oct 1;51(4):225.

25. Lloyd-Sherlock P, Beard J, Minicuci N, Ebrahim S, Chatterji S. Hypertension among older adults in lowand middle-income countries: prevalence, awareness and control. International journal of epidemiology. 2014 Feb 1;43(1):116-28.

26. Bhagyalaxmi A, Atul T, Shikha J. Prevalence of risk factors of non-communicable diseases in a District of Gujarat, India. Journal of health, population, and nutrition. 2013 Mar; 31(1):78.

27. Garg A, Anand T, Sharma U, Kishore J, Chakraborty $M$, Ray PC, Ingle GK. Prevalence of risk factors for chronic non-communicable diseases using who steps approach in an adult population in Delhi. Journal of family medicine and primary care. 2014 Apr; 3(2):112.

28. Bhattacherjee S, Datta S, Roy JK, Chakraborty M. A Cross-sectional Assessment of Risk Factors of Non-
Communicable Diseases in a Sub-Himalayan Region of West Bengal, India Using WHO STEPS Approach. J Association Physicians India. 2015 Dec;63(12):34-40.

29. Mohan V, Deepa M, Farooq S, Datta M, Deepa R. Prevalence, awareness and control of hypertension in Chennai-the Chennai urban rural epidemiology study (CURES-52). Journal of Association of Physicians of India. 2007 May 1; 55:326.

30. Prabhakaran D, Shah P, Chaturvedi V, Ramakrishnan L, Manhapra A, Reddy KS. Cardiovascular risk factor prevalence among men in a large industry of northern India. National Medical Journal of India. 2005 Apr;18(2):59.

31. Midha T, Idris MZ, Saran RK, Srivastava AK, Singh SK. A study on the association between hypertensive status and Anthropometric correlates in the Adult Population of Lucknow District, India. Indian J PrevSoc Med. 2009;40(1):50-4.

32. Isezuo SA, Sabir AA, Ohwovorilole AE, Fasanmade OA. Prevalence, associated factors and relationship between prehypertension and hypertension: a study of two ethnic African populations in Northern Nigeria. Journal of human hypertension. 2011 Apr;25(4):224.

33. Agarwal AK, Yunus M, Khan A, Ahmad J. A clinicalepidemiological study of hypertension in rural population of Jawan Block, Distt, Aligarh (UP) India. Journal of the Royal Society of Health. 1994 Feb;114(1):17-9.

34. Bhardwaj R, Kandori A, Marwah R, Vaidya P, Singh B, Dhiman P, Sharma A. Prevalence, awareness and control of hypertension in rural communities of Himachal Pradesh. J Assoc Physicians India. 2010 Jul; 58:423-4.

35. Das SK, Sanyal K, Basu A. Study of urban community survey in India: growing trend of high prevalence of hypertension in a developing country. International journal of medical sciences. 2005;2(2):70.

36. Chandwani $\mathrm{H}$, Pandor J, Jivarajani $\mathrm{P}$, Jivarajani $\mathrm{H}$. Prevalence and correlates of hypertension among adults in the urban area of Jamnagar, Gujarat, India. Electronic physician. 2010 Jan 1;2(2):52-9.

37. Hypertension Study Group. Prevalence, awareness, treatment and control of hypertension among the elderly in Bangladesh and India: a multicentre study. Bulletin of the World Health Organization. 2001; 79(6):490.

38. Jonas JB, Nangia V, Matin A, Joshi PP, Ughade SN. Prevalence, awareness, control, and associations of arterial hypertension in a rural central India population: the Central India Eye and Medical Study. American journal of hypertension. 2010 Apr 1; 23(4):347-50. 